\title{
Carboxylate Group Side-Chain Density Modulates the pH-Dependent Optical Properties of PPEs
}

\author{
Ik-Bum Kim, Ronnie L. Phillips, and Uwe H. F. Bunz* \\ School of Chemistry and Biochemistry, Georgia Institute of Technology, 901 Atlantic Dr., \\ Atlanta, GA 30332, USA. Fax: 01(404)385-1795; Tel: 01(404)385-1795; E-mail: \\ uwe.bunz@chemistry.gatech.edu \\ Supporting Information (SI)
}

Numbering Scheme in the SI is different from the Numbering Scheme in the manuscript. Red bold numbers indicate the numbering used in the manuscript for the PPEs

Instrumentation and Materials. All chemicals and solvents were used without further purification as received unless otherwise noted. UV-VIS measurements were made with a Shimadzu UV-2401PC recording spectrophotometer. Fluorescence data were obtained with a Shimadzu RF-5301PC spectrofluorophotometer in quartz cuvettes. The fluorescence was recorded at room temperature. Solutions of carboxylate-substituted PPEs were prepared in 0.1 $\mathrm{M}$ sodium phosphate buffer $(\mathrm{pH}=7.2)$. Concentrations of PPEs were adjusted to $5 \times 10^{-6} \mathrm{M}$ on the basis of the molecular weight of the repeating unit of PPEs. Solutions of 10 metal compounds are prepared in $0.1 \mathrm{M}$ concentration: They are $\mathrm{Zn}\left(\mathrm{ClO}_{4}\right)_{2}, \mathrm{CdCl}_{2}, \mathrm{Hg}\left(\mathrm{O}-\mathrm{CO}-\mathrm{CF}_{3}\right)_{2}$, $\mathrm{Pb}\left(\mathrm{NO}_{3}\right)_{2}, \mathrm{FeCl}_{3}, \mathrm{NiCl}_{2}, \mathrm{CoCl}_{2}, \mathrm{CuBr}_{2}, \mathrm{Ca}\left(\mathrm{NO}_{3}\right)_{2}$, and $\mathrm{Mg}(\mathrm{OTf})_{2}$. Quantum yield was measured by using quinine sulfate in $0.1 \mathrm{~N}$ sulfuric acid as a reference $(\Phi=0.54)$ according to ref. 1 .

\section{Scheme 1. Synthesis of monomer 3 and PPE 6 (5b)}
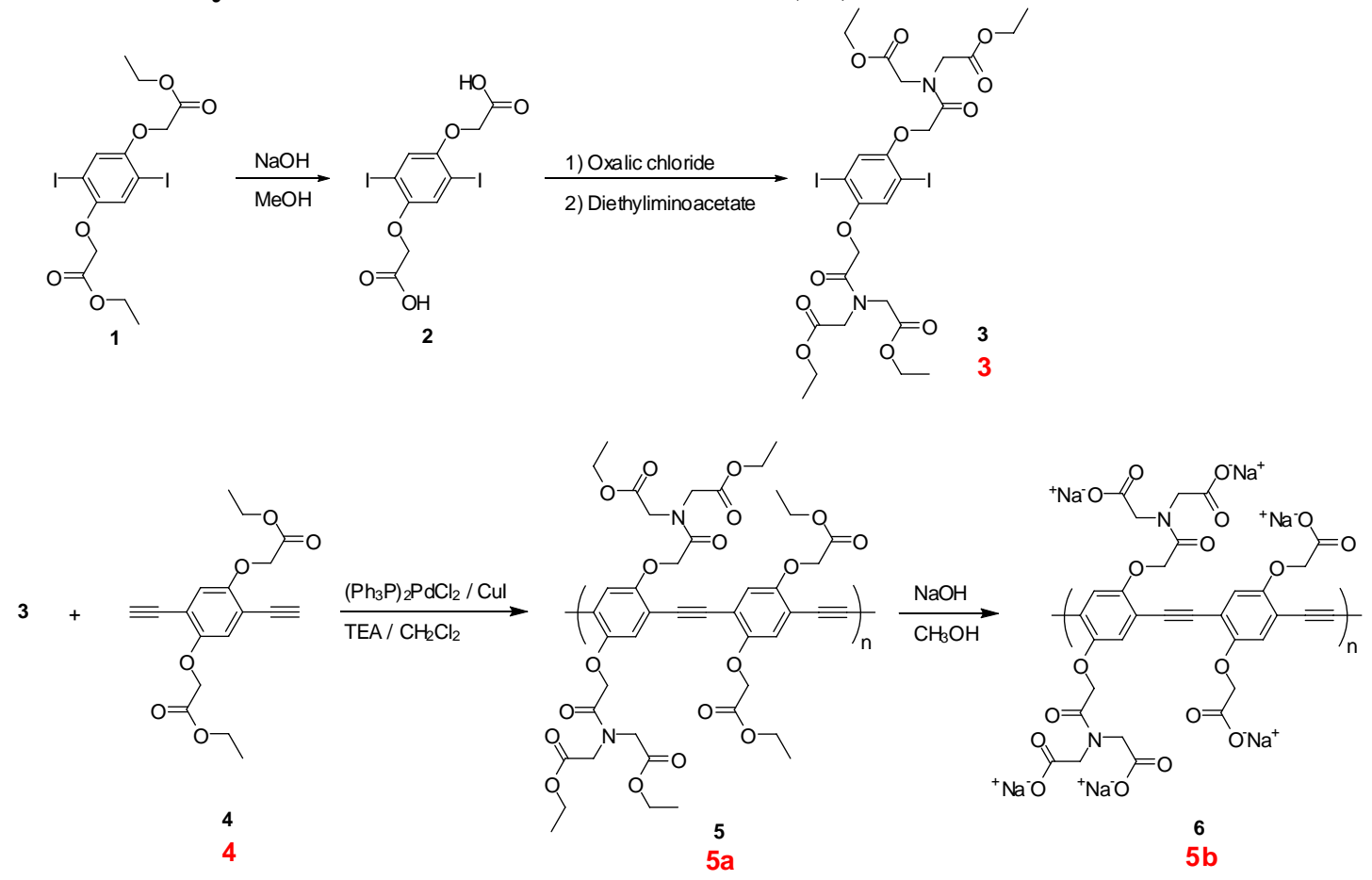

Synthesis of 1 and 3. Compounds 1 and $\mathbf{4}$ were synthesized according to the previous report ${ }^{2}$. 
Synthesis of 2. Compound 1 (2.67 g, $5.00 \mathrm{mmol})$, sodium hydroxide (4.0 g, $0.1 \mathrm{~mol})$, methanol $(60 \mathrm{~mL})$, and water $(3 \mathrm{~mL})$ were placed into a $250 \mathrm{~mL}$ round-bottom flask and heated to reflux for $48 \mathrm{~h}$. The mixture was allowed to cool down to room temperature and the solvent was removed under reduced pressure. The resulting solid was washed with acetone and dissolved in water. Upon the addition of $1 \mathrm{~N}$ sulfuric acid, the precipitate was formed and collected. The colorless solid was obtained in $62 \%$ yield $(1.48 \mathrm{~g}, 3.10 \mathrm{mmol})$.

Synthesis of 3. Compound 2 (10.50 g, $22.0 \mathrm{mmol})$, and oxalyl chloride $(20 \mathrm{~mL})$ were placed into a $50 \mathrm{~mL}$ round-bottom flask and heated to reflux for $24 \mathrm{~h}$. The mixture was allowed to cool down to room temperature and excess oxalylic chloride was removed under reduced pressure. The resulting product, diethyl iminoacetate $(6.23 \mathrm{~g}, 32.9 \mathrm{mmol})$, trimethylamine $(7.58 \mathrm{~g}, 74.8$ $\mathrm{mmol})$, and dichloromethane $(120 \mathrm{~mL})$ were placed in a $250 \mathrm{~mL}$ round bottom flask and the reaction mixture was stirred at room temperature for $16 \mathrm{~h}$. The solvent mixture was removed under reduced pressure and water $(20 \mathrm{~mL})$ was added to the crude product. The precipitate was collected and washed with water. The colorless solid was obtained in $46 \%$ yield $(8.29 \mathrm{~g}, 10.1$ mmol). ${ }^{1} \mathrm{H}$ NMR (300 MHz, $\left.\mathrm{CDCl}_{3}\right): \delta 7.24(\mathrm{~s}, 2 \mathrm{H}), 4.72(\mathrm{~s}, 4 \mathrm{H}), 4.31(\mathrm{~s}, 4 \mathrm{H}), 4.21-4.17(\mathrm{~m}$, $12 \mathrm{H}), 1.25(\mathrm{t}, 12 \mathrm{H}) .{ }^{13} \mathrm{C}$ NMR $\left(300 \mathrm{MHz}, \mathrm{CDCl}_{3}\right): \delta 168.90,168.72,168.09,152.89,123.89$, $86.17,69.55,62.21,61.72,50.04,48.63,14.42$. IR $\left(\mathrm{cm}^{-1}\right): v 3088,2986,1725,1680,1485,1466$, 1225, 1195, 1022, 873, 757. MS (ESI): $[\mathrm{M}+\mathrm{H}]^{+} \mathrm{m} / \mathrm{z} 821.0$.

Synthesis of polymer 5 (5a): Monomer $3(820 \mathrm{mg}, 1.00 \mathrm{mmol})$ and monomer 4 (347 mg, 1.05 $\mathrm{mmol})$ were dissolved in chloroform $(2 \mathrm{~mL})$, THF $(2 \mathrm{~mL})$, and triethylamine $(1 \mathrm{~mL})$ in an oven dried Schlenk flask. The flask was flushed with nitrogen and frozen and evacuated three times after which $\left(\mathrm{Ph}_{3} \mathrm{P}\right)_{2} \mathrm{PdCl}_{2}(1.4 \mathrm{mg}, 2 \mu \mathrm{mol})$, and $\mathrm{CuI}(0.4 \mathrm{mg}, 2 \mu \mathrm{mol})$ were added. The mixture was allowed to stir at room temperature for $48 \mathrm{~h}$. The solution was slowly added to ether (200 $\mathrm{mL}$ ), the precipitate was collected and washed with ether. An orange solid was obtained in $96 \%$ yield $(863 \mathrm{mg})$. The weight average molecular weight was estimated to be $3.6 \times 10^{4}$ with a polydispersity $\left(\mathrm{M}_{\mathrm{w}} / \mathrm{M}_{\mathrm{n}}\right)$ of $2.10 .{ }^{1} \mathrm{H}$ NMR $\left(500 \mathrm{MHz}, \mathrm{DMSO}-\mathrm{d}_{6}\right): \delta 7.19(2 \mathrm{H}), 7.05(2 \mathrm{H}), 4.97$ $(4 \mathrm{H}), 4.39(4 \mathrm{H}), 4.13(12 \mathrm{H}), 3.72(8 \mathrm{H}), 1.18(18 \mathrm{H}) . \quad$ IR $\left(\mathrm{cm}^{-1}\right): v 3622,3488,2985,2204,1745$, $1680,1507,1271,1189,1080,1025,971,868,741$. Due to low solubility, ${ }^{13} \mathrm{C}$ NMR spectrum could not be obtained.

Synthesis of polymer 6 (5b). Polymer 5 (5a) (200 mg, $0.22 \mathrm{mmol}$ ), sodium hydroxide (400 mg, $10 \mathrm{mmol})$, and methanol $(30 \mathrm{~mL})$ were placed into a $100 \mathrm{~mL}$ round-bottom flask and heated to reflux for $48 \mathrm{~h}$. The mixture was allowed to cool down to room temperature and the solvent was removed under reduced pressure. The resulting solid was washed with acetone and dissolved in water. The polymer was deprotected in $1 \mathrm{M} \mathrm{NaOH}$ and EDTA $(150 \mathrm{mg})$ was added to complex any residual copper. The resulting solution was neutralized with $1 \mathrm{M} \mathrm{HCl}$, dialyzed against DI $\mathrm{H}_{2} \mathrm{O}$ for $3 \mathrm{~d}$, and the solvent was removed resulting in a dark orange solid (179 $\mathrm{mg}, 0.20 \mathrm{mmol}$, 91\% yield). ${ }^{1} \mathrm{H}$ NMR (500 MHz, $\left.\mathrm{D}_{2} \mathrm{O}\right): \delta 4.91(4 \mathrm{H}), 4.58(4 \mathrm{H}), 3.98(8 \mathrm{H}) . \quad \mathrm{IR}\left(\mathrm{cm}^{-1}\right): v 3350$, 2894, 2203, 1652, 1593, 1406, 1327, 1208, 1116, 1040, 980, 932, 850, 720. $\Phi_{\text {water }}=0.08$. Due to low solubility, ${ }^{13} \mathrm{C}$ NMR spectrum could not be obtained.

Scheme 2. Synthesis of monomer $\mathbf{1 1}^{3,4}$ 

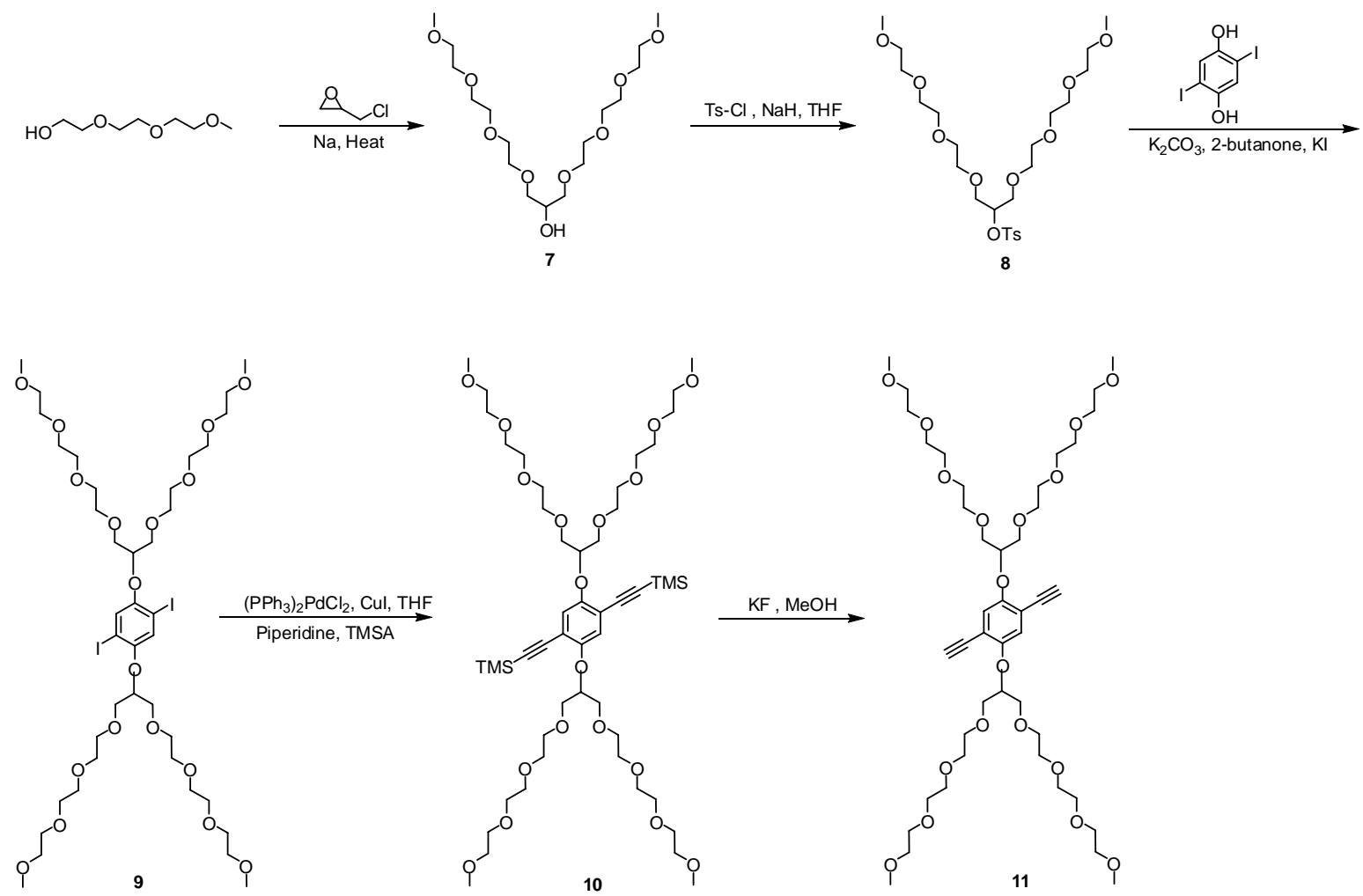

Synthesis of 7. Triethyleneglycol-monomethylether ( $200 \mathrm{~g}, 1.22 \mathrm{~mol})$ was added to a dry 1000 $\mathrm{mL}$ Schlenk flask. While under $\mathrm{N}_{2}$ at $100^{\circ} \mathrm{C}$, Na metal $(10.0 \mathrm{~g}, 0.440 \mathrm{~mol})$ was added slowly and stirred until all $\mathrm{Na}$ metal had reacted. Upon reaction of $\mathrm{Na}$, solution was cooled to $65^{\circ} \mathrm{C}$, and epichlorohydrin $(37.0 \mathrm{~g}, 0.400 \mathrm{~mol}, 31.4 \mathrm{~mL})$ was added drop-wise. Upon complete addition of epichlorohydrin, reaction mixture was heated to $100^{\circ} \mathrm{C}$, and allowed to react for 3 days. After completion of the reaction, $\mathrm{NH}_{4} \mathrm{Cl}(0.400 \mathrm{~mol}, 24.1 \mathrm{~g})$ was added and reacted at $100^{\circ} \mathrm{C}$ for $1 \mathrm{~h}$. The reaction was cooled to room temperature, filtered to remove excess salts, and purified by distillation. The first fraction contained excess starting material, while the second fraction contained product as a light yellowish oil $(70.2 \mathrm{~g}, 0.182 \mathrm{~mol}, 45.6 \%)$. ${ }^{1} \mathrm{H}$ NMR $(300 \mathrm{MHz}$, $\left.\mathrm{CDCl}_{3}\right): \delta 3.64(\mathrm{~m}, 1 \mathrm{H}), 3.40-3.22(\mathrm{~m}, 28 \mathrm{H}), 3.06(\mathrm{~s}, 6 \mathrm{H}), 2.84(\mathrm{~s}, 1 \mathrm{H}) .{ }^{13} \mathrm{C} \mathrm{NMR}(300 \mathrm{MHz}$, $\left.\mathrm{CDCl}_{3}\right): \delta 72.63,71.87,70.67,70.49,70.41,69.27,58.87 . \mathrm{IR}\left(\mathrm{cm}^{-1}\right): v 3463,2871,1454,1350$, $1296,1247,1199,1107,943,850$. MS (ESI): $[\mathrm{M}+\mathrm{H}]^{+} \mathrm{m} / \mathrm{z} 385.2$.

Synthesis of 8. Compound $7(15.0 \mathrm{~g}, 0.0390 \mathrm{~mol})$ was dissolved in dry THF $(250 \mathrm{~mL})$. While under $\mathrm{N}_{2}$, the solution was cooled to $0^{\circ} \mathrm{C}$ and $\mathrm{NaH}(1.2 \mathrm{eq}, 0.0468 \mathrm{~mol}, 1.12 \mathrm{~g})$ was added. Upon cessation of $\mathrm{H}_{2}$, Ts-Cl $(0.0390 \mathrm{~mol}, 7.43 \mathrm{~g})$ was dissolved in dry THF $(50 \mathrm{~mL})$ and added to the previous solution. The reaction mixture was warmed to room temperature and reacted overnight. The resulting solution was filtered, the solvent was removed, and the crude oil was dried under oil pump vacuum at 0.1 Torr. The product was purified by silica gel chromatography (10:1 EtOAc/MeOH). The product was an orange oil $(15.1 \mathrm{~g}, 0.0279 \mathrm{~mol}, 71.6 \%) .{ }^{1} \mathrm{H}$ NMR $(300$ $\left.\mathrm{MHz}, \mathrm{CDCl}_{3}\right): \delta 7.61(\mathrm{~d}, 2 \mathrm{H}), 7.18(\mathrm{~d}, 2 \mathrm{H}), 4.51(\mathrm{~m}, 1 \mathrm{H}), 3.50-3.28(\mathrm{~m}, 28 \mathrm{H}), 3.18(\mathrm{~s}, 6 \mathrm{H}), 2.25$ (s, 3H). ${ }^{13} \mathrm{C}$ NMR (300 MHz, $\left.\mathrm{CDCl}_{3}\right): \delta 144.00,133.51,129.09,127.43,79.14,71.34,70.31$, 
70.01, 69.78, 69.08, 58.39, 21.06. IR $\left(\mathrm{cm}^{-1}\right): v 2871,1597,1454,1361,1292,1245,1190,1105$, 929, 777, 665, 555. MS (ESI): [M+H] $]^{+} \mathrm{m} / z$ 539.3.

Synthesis of 9. A suspension of 1,4-dihydroxy-2,5-diiodobenzene (5.01 g, $0.0138 \mathrm{~mol})$, compound 8 (15.0 g, $0.0278 \mathrm{~mol})$, and $\mathrm{K}_{2} \mathrm{CO}_{3}$ (4 eq., $7.64 \mathrm{~g}, 0.0553 \mathrm{~mol}$ ) were dissolved in a minimal amount of 2-butanone $(75 \mathrm{~mL})$ and heated to reflux. A small amount of KI was added to promote the reaction by exchanging with tosylate. The mixture was reacted for 5 days. The reaction mixture was cooled to room temperature, diluted with $\mathrm{CH}_{2} \mathrm{Cl}_{2}(250 \mathrm{~mL})$, and filtered with celite to remove the black insoluble residue. The solution was concentrated in vacuo to remove the solvent and the crude oil was purified by silica gel chromatography (90:10 EtOAc/MeOH) yielding a viscous orange oil $(6.20 \mathrm{~g}, 0.00567 \mathrm{~mol}, 41.0 \%)$. ${ }^{1} \mathrm{H} \mathrm{NMR}(500 \mathrm{MHz}$, $\left.\mathrm{CDCl}_{3}\right): \delta 7.31(\mathrm{~s}, 2 \mathrm{H}), 4.25(\mathrm{~m}, 2 \mathrm{H}), 3.51-3.35(\mathrm{~m}, 56 \mathrm{H}), 3.21(\mathrm{~s}, 12 \mathrm{H}) .{ }^{13} \mathrm{C} \mathrm{NMR}(500 \mathrm{MHz}$, $\left.\mathrm{CDCl}_{3}\right): \delta 153.44,126.17,88.11,80.87,71.98,71.23,70.94,70.62,70.55,59.14 . \quad$ IR $\left(\mathrm{cm}^{-1}\right): v$ 2871.8, 1658.7, 1463.9, 1328.9, 12856.4, 1247.9, 1199.6, 1095.5, 941.2, 852.5, 777.3, 732.9.

Synthesis of 10. Compound $9(4.61 \mathrm{~g}, 4.11 \mathrm{mmol})$ was dissolved in dry THF $(5 \mathrm{~mL})$ and stirred under $\mathrm{N}_{2}$ for $15 \mathrm{~min}$. Upon degassing, $\mathrm{CuI}$ (0.01 eq., $\left.0.042 \mathrm{mmol}, 8.1 \mathrm{mg}\right),\left(\mathrm{PPh}_{3}\right)_{2} \mathrm{PdCl}_{2}(0.01$ eq., $0.042 \mathrm{mmol}, 29.5 \mathrm{mg})$, piperidine ( $5 \mathrm{~mL}$ ), and TMS-acetylene (4 eq., $16.8 \mathrm{mmol}, 2.39 \mathrm{~mL}$ ) were all added to the reaction. The reaction was stirred at room temperature for $2 \mathrm{~d}$. The reaction mixture was diluted with THF $(25 \mathrm{~mL})$ and filtered to remove any excess salts. The solvent was removed and the crude product was purified by silica gel chromatography (9:1 EtOAc / MeOH). The resulting product was an orange oil $(3.62 \mathrm{~g}, 3.40 \mathrm{mmol}, 83.0 \%)$. ${ }^{1} \mathrm{H} \mathrm{NMR}(500 \mathrm{MHz}$, $\left.\mathrm{CDCl}_{3}\right): \delta 7.08(\mathrm{~s}, 2 \mathrm{H}), 4.35(\mathrm{~m}, 2 \mathrm{H}), 3.75-3.41(\mathrm{~m}, 56 \mathrm{H}), 3.30(\mathrm{~s}, 12 \mathrm{H}), 0.2(\mathrm{~s}, 18 \mathrm{H}) .{ }^{13} \mathrm{C} \mathrm{NMR}$ $\left(500 \mathrm{MHz}, \mathrm{CDCl}_{3}\right): \delta 153.69,121.11,115.61,100.85,99.76,79.62,71.68,70.94,70.39,70.33$, 70.27, 58.78, 0.00. IR ( $\left.\mathrm{cm}^{-1}\right): v 3018,2891,2204,1489,1396,1351,1216,1099,1028,928,850$, 758.

Synthesis of 11. Compound 10 (3.62 g, $3.40 \mathrm{mmol}$ ) was dissolved in $\mathrm{MeOH}$ (50 mL). KF (4 eq., $1.07 \mathrm{~g}, 0.0140 \mathrm{~mol})$ was dissolved in $\mathrm{MeOH}(25 \mathrm{~mL})$ and added to the previous solution. The reaction was stirred overnight at room temperature. The solvent was removed and the crude product was re-dissolved in $\mathrm{CHCl}_{3}$. The solution was extracted with $\mathrm{H}_{2} \mathrm{O}$ and the organic fractions were collected and concentrated in vacuo. The crude product was purified by silica gel chromatography (10:1 EtOAc / MeOH) which resulted in an orange oil (2.64 g, $2.96 \mathrm{mmol}, 87.1$ \%). ${ }^{1} \mathrm{H}$ NMR (500 MHz, $\left.\mathrm{CDCl}_{3}\right): \delta 7.05(\mathrm{~s}, 2 \mathrm{H}), 4.30(\mathrm{~m}, 2 \mathrm{H}), 3.68-3.50(\mathrm{~m}, 56 \mathrm{H}), 3.41(\mathrm{~s}$, $12 \mathrm{H}), 3.25$ (s, 2H). ${ }^{13} \mathrm{C} \mathrm{NMR}\left(500 \mathrm{MHz}, \mathrm{CDCl}_{3}\right): \delta 154.31,121.67,115.20,83.00,80.18,79.54$, 72.06, 71.30, 70.76, 70.71, 70.64, 59.15. IR $\left(\mathrm{cm}^{-1}\right): v 3302,3019,2891,2201,1489,1394,1338$, 1217, 1099, 1028, 926, 850, 758. MS (ESI): $[\mathrm{M}+\mathrm{H}]^{+} \mathrm{m} / z$ 891.5. 
Scheme 3. Synthesis of polymer 13 (9).

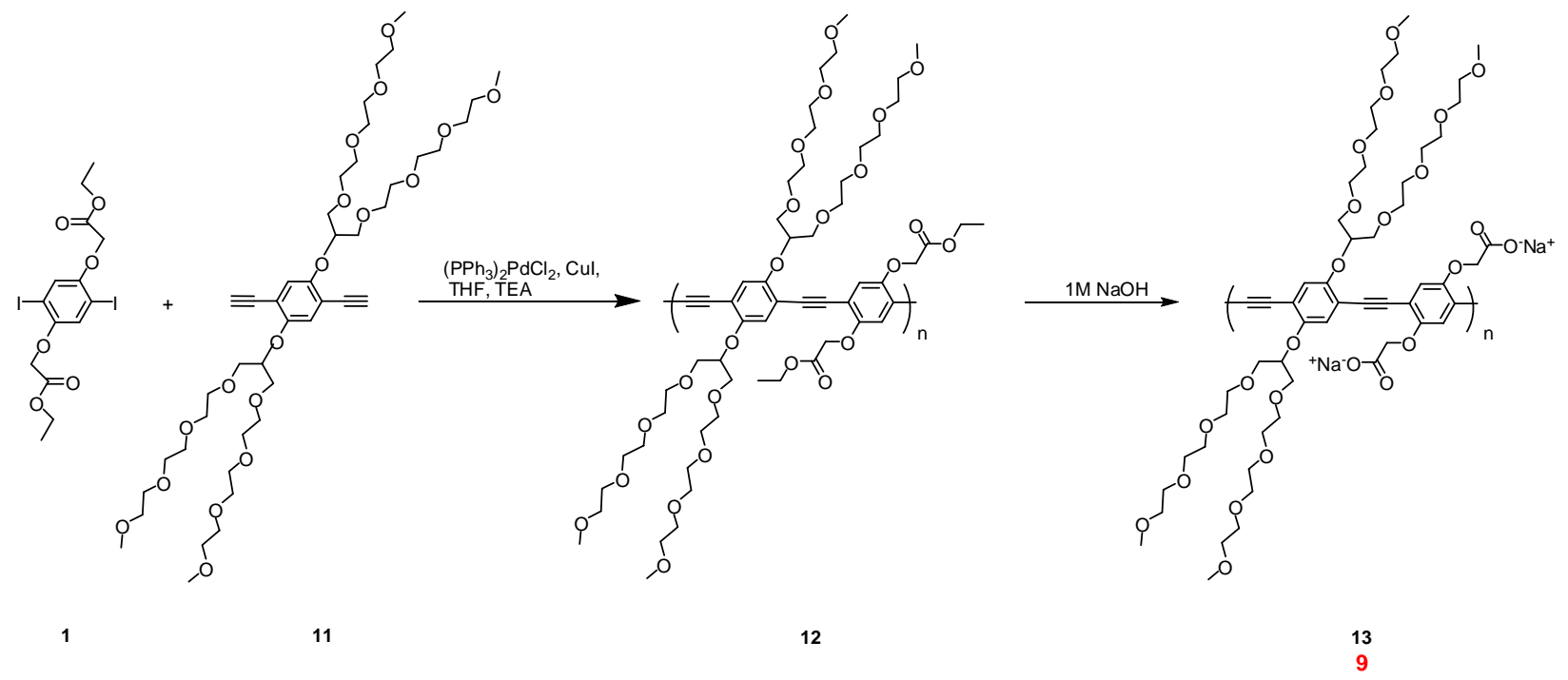

Synthesis of polymer 12: Compound 11 (890 mg, $1 \mathrm{mmol})$, compound 1 (534 mg, $1 \mathrm{mmol})$, THF $(3 \mathrm{~mL})$, and TEA $(3 \mathrm{~mL})$ were all combined in a $25 \mathrm{~mL}$ Schlenk tube. Upon degassing, $\left(\mathrm{PPh}_{3}\right)_{2} \mathrm{PdCl}_{2}(0.5 \mathrm{~mol} \%, 3.51 \mathrm{mg})$, and $\mathrm{CuI}(1 \mathrm{~mol} \%, 1.91 \mathrm{mg})$ were added to the mixture under $\mathrm{N}_{2}$ and allowed to react for $2 \mathrm{~d}$. The solvent was removed under vacuum and the polymer was re-dissolved in $\mathrm{CHCl}_{3}$. The polymer solution was extracted with $\mathrm{H}_{2} \mathrm{O}(3 \mathrm{x})$, the organic fractions were collected, and the solvent was removed which resulted in an orange solid (680 $\mathrm{mg}, 0.60$ mmol, 60\%). GPC (vs. polystyrene standards in chloroform): $\mathrm{M}_{\mathrm{n}}=2.5 \times 10^{4}, \mathrm{M}_{\mathrm{w}} / \mathrm{M}_{\mathrm{n}}=1.8, \mathrm{n}=$ 21. ${ }^{1} \mathrm{H}$ NMR $\left(500 \mathrm{MHz}, \mathrm{CDCl}_{3}\right): \delta 7.33(\mathrm{~s}, 2 \mathrm{H}), 7.14(\mathrm{~s}, 2 \mathrm{H}), 4.78(\mathrm{~s}, 4 \mathrm{H}), 4.54(\mathrm{~m}, 2 \mathrm{H}), 4.20(\mathrm{~m}$, $4 \mathrm{H}), 3.87-3.38(\mathrm{~m}, 56 \mathrm{H}), 3.11(\mathrm{~s}, 12 \mathrm{H}), 1.28(\mathrm{t}, 6 \mathrm{H}) .{ }^{13} \mathrm{C}$ NMR $\left(500 \mathrm{MHz}, \mathrm{CDCl}_{3}\right): \delta 168.03$, $154.65,151.23,124.65,120.22,117.06,115.31,92.35,91.76,80.34,72.45,71.68,71.02,70.77$, $70.32,66.87,61.32,59.32,13.74$.

Synthesis of polymer 13 (9): Polymer 12 (660 mg, $0.56 \mathrm{mmol})$ was deprotected in $1 \mathrm{M} \mathrm{NaOH}$ and EDTA $(250 \mathrm{mg}$ ) was added to complex any residual copper. The resulting solution was neutralized with $1 \mathrm{M} \mathrm{HCl}$, dialyzed against $\mathrm{DI} \mathrm{H}_{2} \mathrm{O}$ for $3 \mathrm{~d}$, and the solvent was removed resulting in a dark orange flaky solid. ${ }^{1} \mathrm{H}$ NMR $\left(500 \mathrm{MHz}, \mathrm{D}_{2} \mathrm{O}\right): \delta 7.12(\mathrm{~s}, 2 \mathrm{H}), 6.97(\mathrm{~s}, 2 \mathrm{H})$, $4.61(\mathrm{~s}, 4 \mathrm{H}), 4.43(\mathrm{~m}, 2 \mathrm{H}), 3.79-3.41(\mathrm{~m}, 56 \mathrm{H}), 3.27(\mathrm{~s}, 12 \mathrm{H})$. IR $\left(\mathrm{cm}^{-1}\right): v 3422,2919,2204$, $1613,1489,1405,1350,1275,1208,1088,944,852 . \Phi_{\text {water }}=0.33$. Due to low solubility, ${ }^{13} \mathrm{C}$ NMR spectrum could not be obtained. 
Experiment 1. Quenching of the fluorescence of polymer 6 (5b) upon the addition of metal ions and its photophysics in water.

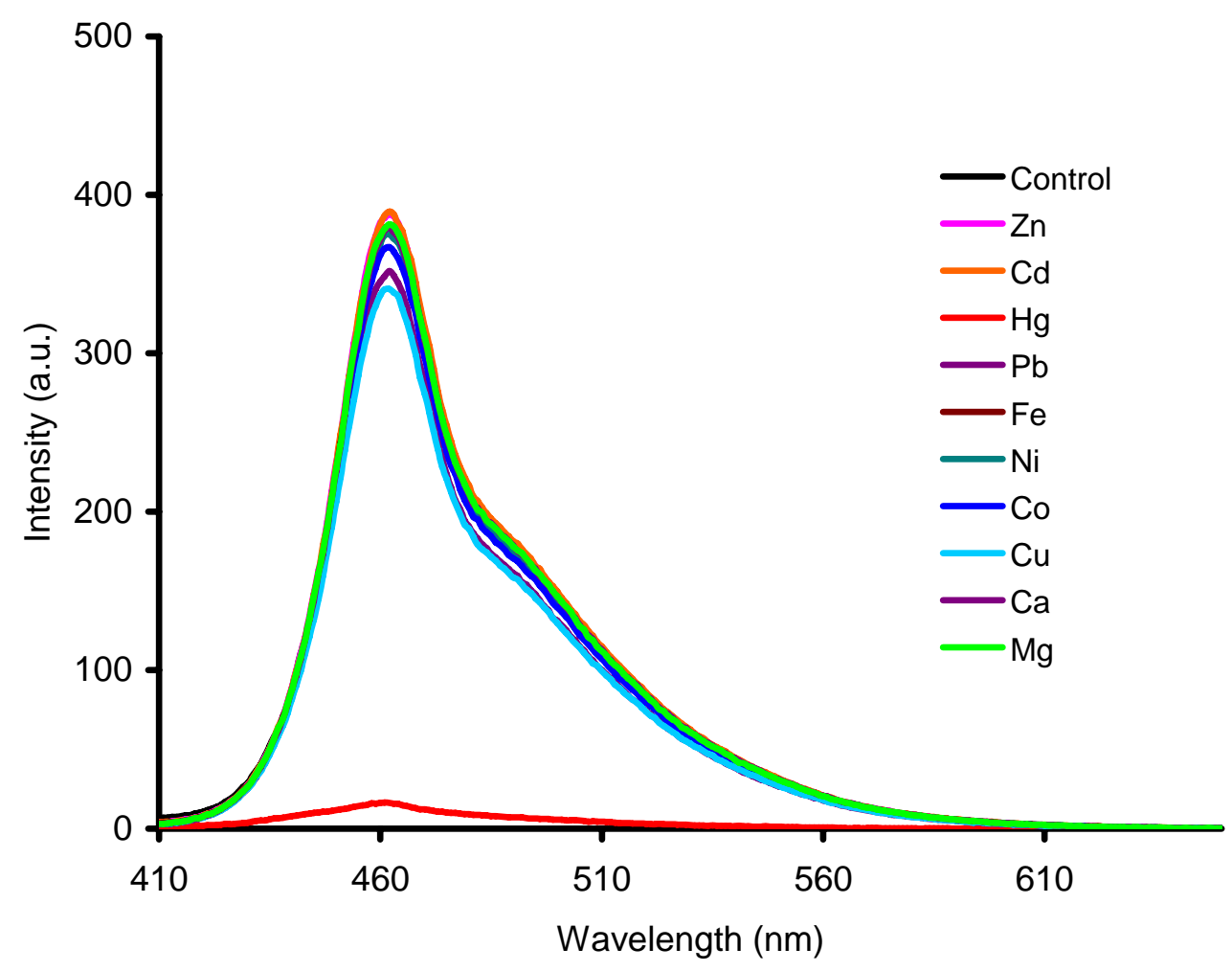

Figure 1. Emission spectra of polymer 6 (5b) with $20 \mu \mathrm{L}$ of $0.1 \mathrm{M}$ divalent metal salt solutions in $5 \mathrm{~mL}$ of $0.1 \mathrm{M}$ phosphate buffer ( $\mathrm{pH} 7.2$ ).

a)

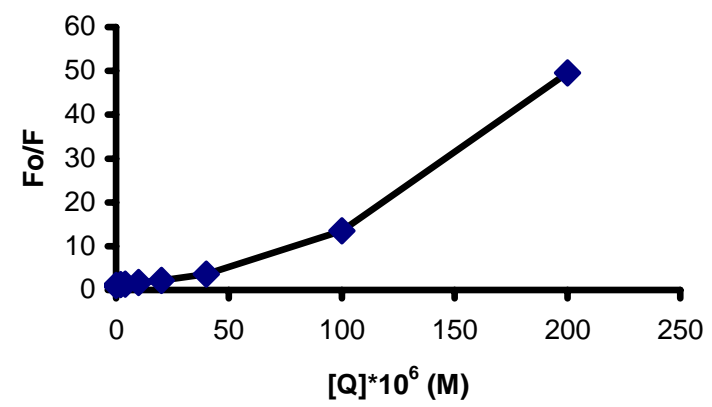

b)

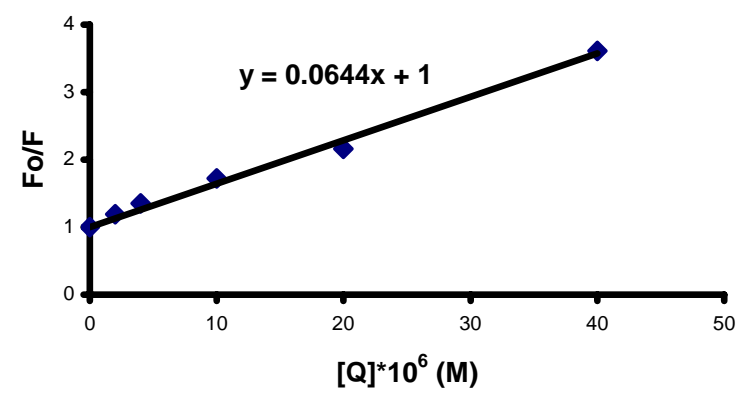

Figure 2. a) Stern-Volmer plot of polymer 6 (5b) with $\mathrm{Hg}^{2+}$ ions, b) The $\mathrm{K}_{\mathrm{sv}}$ is $6.4 \times 10^{4} \mathrm{M}^{-1}$ for the linear region of the curve. 
a)

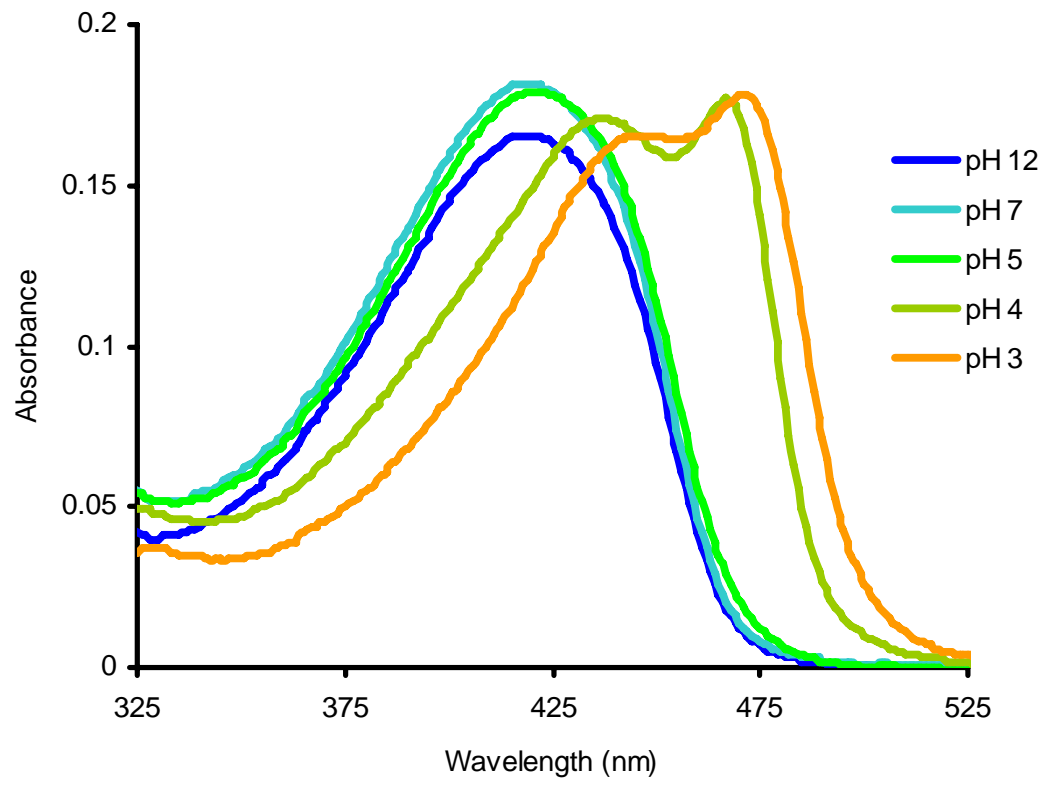

b)

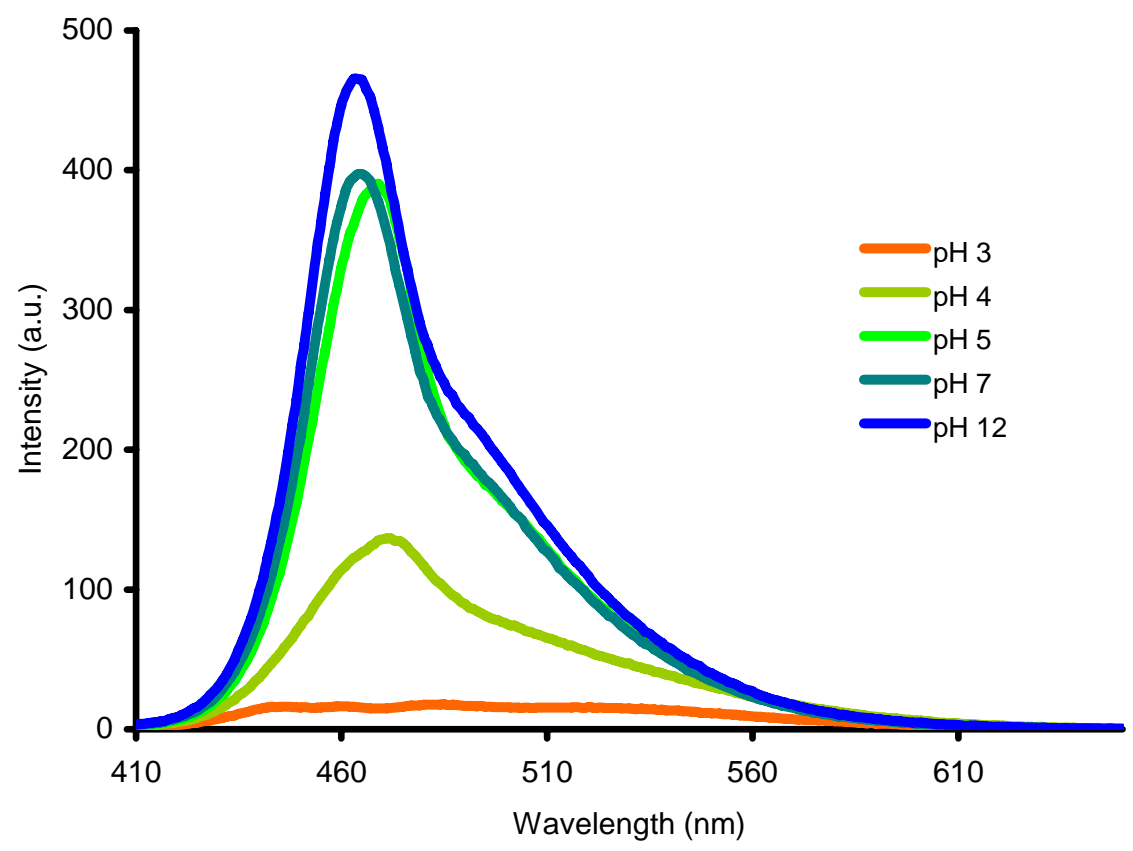

Figure 3. Photophysical response of polymer 6 (5b) upon changing the $\mathrm{pH}$. a) Absorption spectra of polymer 6 from $\mathrm{pH} 3-12, \mathrm{~b})$ Emission spectra of polymer 6 from $\mathrm{pH}=3-12$. 
Experiment 2. Quenching of the fluorescence of polymer 13 (9) upon the addition of divalent metal ions and its photophysics in water.

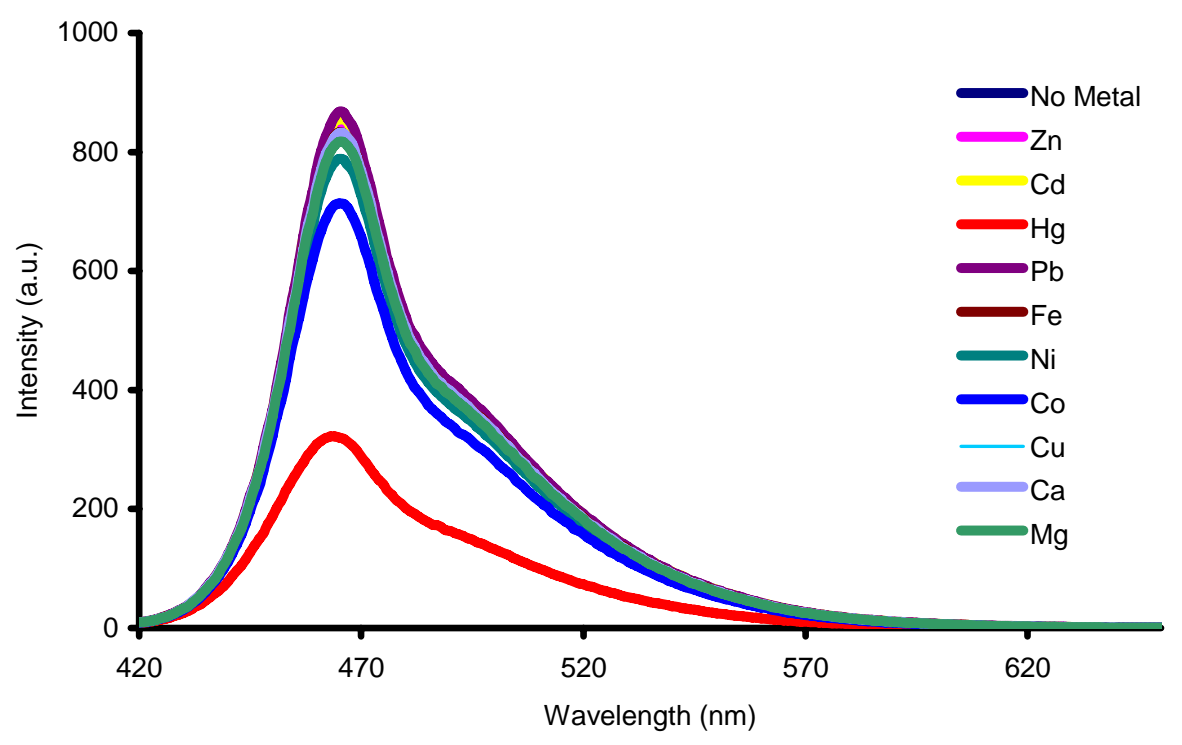

Figure 4. Emission spectra of polymer 13 (9) with $50 \mu \mathrm{L}$ of $0.1 \mathrm{M}$ metal salt solutions in $5 \mathrm{~mL}$ of $0.1 \mathrm{M}$ phosphate buffer ( $\mathrm{pH} 7.2$ ).

a)

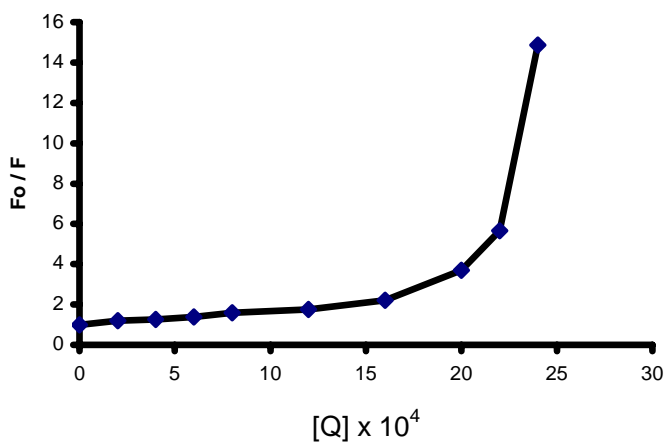

b)

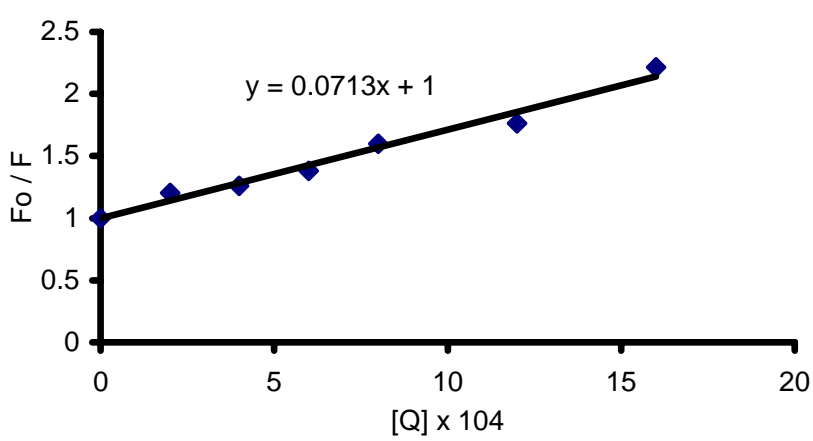

Figure 5. a) Stern-Volmer plot of quenching of polymer 13 (9) with $\mathrm{Hg}^{2+}$ ions, b) The $\mathrm{K}_{\mathrm{sv}}$ is $7.13 \times 10^{2} \mathrm{M}^{-1}$ for the linear region of the curve. 
a)

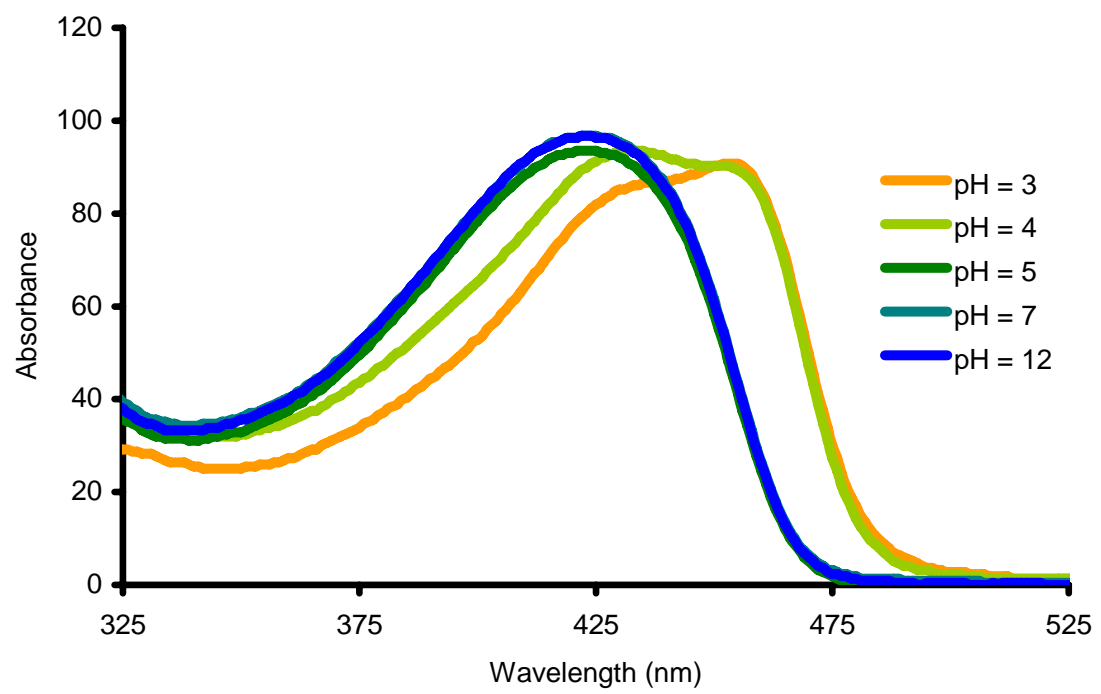

b)

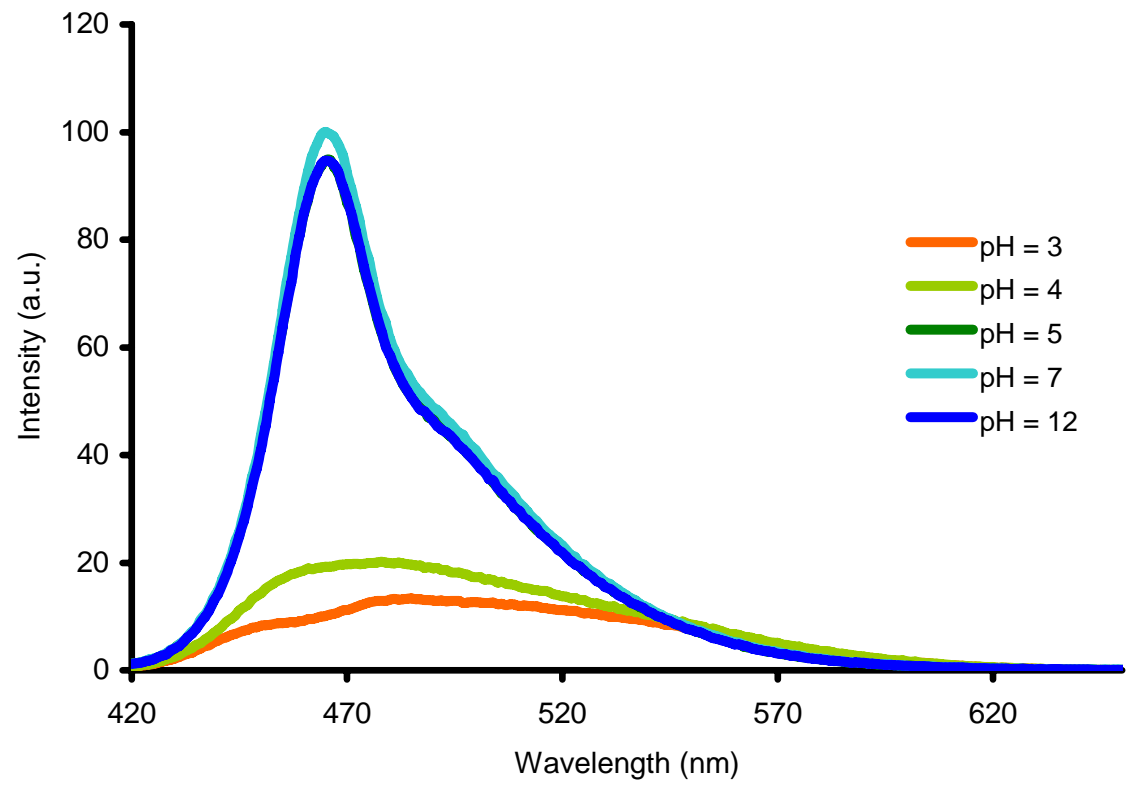

Figure 6. Photophysical response of polymer 13 (9) upon changing the $\mathrm{pH}$. a) Absorption spectra of 13 from $\mathrm{pH} 3-12$, b) Emission spectra of 13 (9) from $\mathrm{pH}=3-12$. 
Experiment 3. Quenching of the fluorescence of polymer 14 (6) upon the addition of divalent metal ions and its photophysics in water.

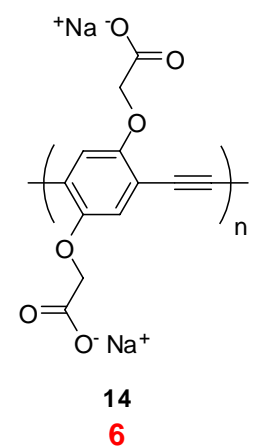

Figure 7. Structure of polymer 14 (6). PPE 14 (6) was synthesized according to the previous report $^{1}$ and had the number average molecular weight of $1.2 \times 10^{4}$ with a polydispersity (Mw/Mn) of 4.3 .

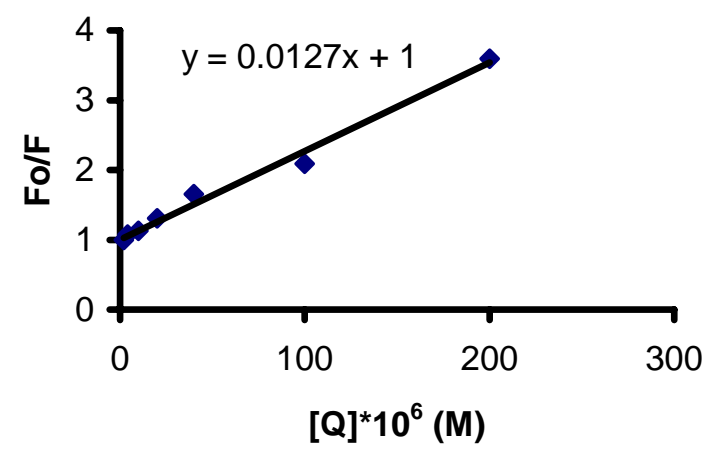

Figure 8. Stern-Volmer plot for polymer 14 (6) with $\mathrm{Hg}^{2+}$ ions. The apparent Stern-Volmer constant $\left(\mathrm{K}_{\mathrm{sv}}\right)$ for $\mathrm{Hg}^{2+}$ ions is $1.3 \times 10^{4}$.

a)

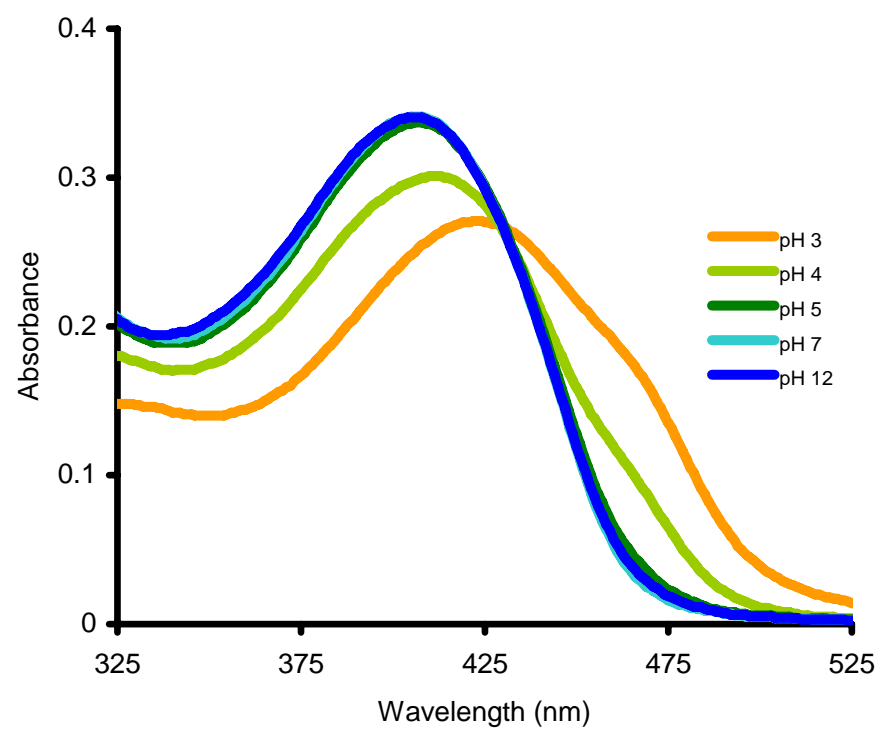


b)

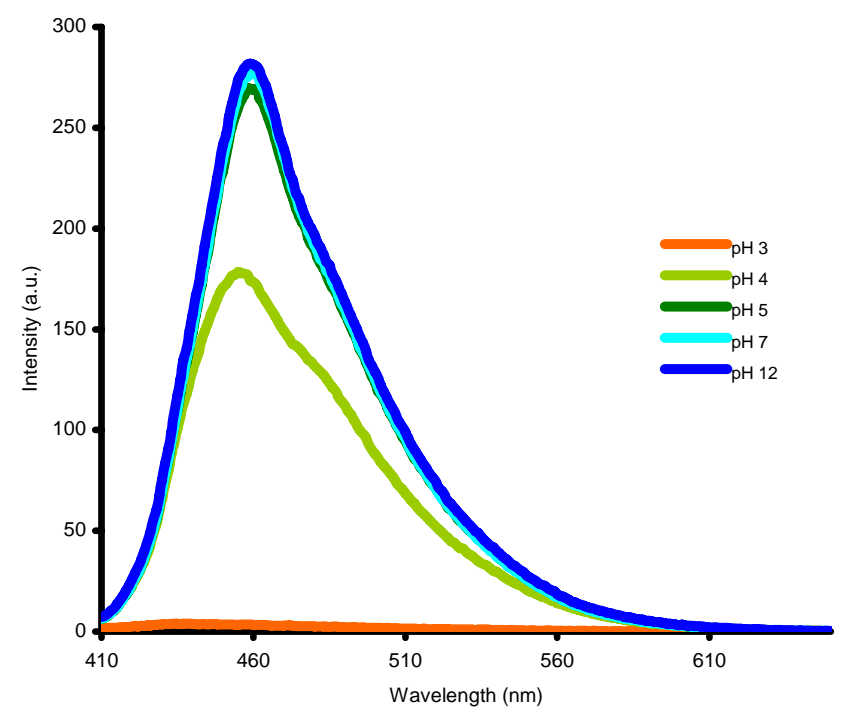

Figure 9. Photophysical response of polymer 14 (6) upon changing the $\mathrm{pH}$. a) Absorption spectra of 14 (6) from $\mathrm{pH} 3-12, \mathrm{~b})$ Emission spectra of 14 (6) from $\mathrm{pH}=3-12$.

\section{References:}

1. We have carried out our quantum yield determination using quinine sulfate according to the procedure described in the following reference: Melhuish, W. H. J. Phys. Chem. 1961, 65, 229235.

2. Kim, I. B.; Dunkhorst, A.; Gilbert, J.; Bunz, U. H. F. Macromolecules 2005, 38, 4560-4562.

3. Lauter, U.; Meyer, W.H.; Enkelmann, V.; Wegner, G. Macromol. Chem. Phys. 1998, 199, 2129-2140.

4. Khan, A.; Muller, S.; Hecht, S. Chem. Commun. 2005, 584-586. 